\title{
Haloaluminate-Free Cationic Aluminum Complexes: Structural Characterization and Physicochemical Properties
}

\author{
Toshihiko Mandai ${ }^{\dagger, *, *}$ and Patrik Johansson ${ }^{\dagger}$ \\ ${ }^{\dagger}$ Department of Physics, Chalmers University of Technology, SE-412 96 Göteborg, Sweden \\ ${ }^{\sharp}$ Present address: Department of Applied Chemistry, Tokyo Metropolitan University, 1-1 \\ Minami-Osawa, Hachioji, Tokyo, 192-0397, Japan
}

CORRESPONDING AUTHOR FOOTNOTES

Telephone: +81-42-677-2826, E-mail: mandai@tmu.ac.jp 


\section{Complete synthesis procedures and analytical data of $\left[\mathrm{Al}(\mathrm{L})_{6}\right] \mathrm{X}_{3}$}

[Al(DMSO $\left.)_{6}\right]\left[\mathrm{TFSI}_{3}:\right.$ To the suspension of $\mathrm{AlCl}_{3}(0.947 \mathrm{~g}, 7.10 \mathrm{mmol})$ in toluene $(10 \mathrm{~mL})$, DMSO

(3.33 g, $42.6 \mathrm{mmol}$ ) was added dropwise and then the mixture was stirred for 24 hours at ambient temperature. The resulting crude compound and LiTFSI $(6.11 \mathrm{~g}, 21.3 \mathrm{mmol})$ was mixed together in acetonitrile $(30 \mathrm{~mL})$ for 2 days at room temperature. After removal of precipitated $\mathrm{LiCl}$ and solvent by filtration and evaporation, the remaining salt was recrystallized three times in acetonitrile to give $\left[\mathrm{Al}(\mathrm{DMSO})_{6}\right][\mathrm{TFSI}]_{3}$ as a colorless crystal $(7.68 \mathrm{~g}, 5.75 \mathrm{mmol}, 80.9 \%)$. Elemental analysis: calculated (\%) for $\mathrm{C}_{18} \mathrm{H}_{36} \mathrm{AlF}_{18} \mathrm{~N}_{3} \mathrm{O}_{18} \mathrm{~S}_{12}$ : C 16.18, $\mathrm{Al}$ 2.02; found: C 16.36, $\mathrm{Al}$ 2.18.

$\left.\left[\mathrm{Al}(\mathrm{DMSO})_{6}\right]_{[\mathrm{TfO}}\right]_{3}$ : To the suspension of $\mathrm{AlCl}_{3}(0.568 \mathrm{~g}, 4.26 \mathrm{mmol})$ in toluene $(10 \mathrm{~mL})$, DMSO $(2.00 \mathrm{~g}, 25.5 \mathrm{mmol})$ was added dropwise and then the mixture was stirred for 24 hours at ambient temperature. The resulting $\left[\mathrm{Al}(\mathrm{DMSO})_{6}\right] \mathrm{Cl}_{3}$ and $\mathrm{NaTfO}(2.20 \mathrm{~g}, 12.8 \mathrm{mmol})$ was mixed together in acetonitrile $(30 \mathrm{~mL})$ for 2 days at room temperature. After the removal of precipitated $\mathrm{NaCl}$ and solvent by filtration and evaporation, the remaining salt was recrystallized three times in acetonitrile to give $\left[\mathrm{Al}(\mathrm{DMSO})_{6}\right][\mathrm{TfO}]_{3}$ as a colorless crystal $(2.71 \mathrm{~g}, 2.87 \mathrm{mmol}, 67.4 \%)$. Elemental analysis: calculated (\%) for $\mathrm{C}_{15} \mathrm{H}_{36} \mathrm{AlF}_{9} \mathrm{O}_{15} \mathrm{~S}_{9}$ : C 19.11, $\mathrm{Al} 2.86$; found: C 19.32, $\mathrm{Al} 3.08$.

$\left[\mathrm{Al}(\mathrm{MIm})_{6}\right][\mathrm{TFSI}]_{3}$ : To the suspension of $\mathrm{AlCl}_{3}(0.488 \mathrm{~g}, 3.66 \mathrm{mmol})$ in toluene $(10 \mathrm{~mL}), \mathrm{MIm}(1.80$ $\mathrm{g}, 22.0 \mathrm{mmol}$ ) was added dropwise and then the mixture was stirred for 24 hours at ambient temperature. The resulting crude compound and LiTFSI $(3.15 \mathrm{~g}, 11.0 \mathrm{mmol})$ was mixed together in acetonitrile $(30 \mathrm{~mL})$ for 2 days at room temperature. After removal of precipitated $\mathrm{LiCl}$ and solvent 
by filtration and evaporation, the remaining salt was recrystallized three times in acetonitrile to give $\left[\mathrm{Al}(\mathrm{MIm})_{6}\right][\mathrm{TFSI}]_{3}$ as a colorless crystal $(3.59 \mathrm{~g}, 2.64 \mathrm{mmol}, 72.1 \%)$. Elemental analysis: calculated (\%) for $\mathrm{C}_{30} \mathrm{H}_{36} \mathrm{AlF}_{18} \mathrm{~N}_{15} \mathrm{O}_{12} \mathrm{~S}_{6}$ : C 26.49, $\mathrm{Al}$ 1.98; found: C 26.59, $\mathrm{Al} 2.18$.

$\left[\mathrm{Al}(\mathrm{BIm})_{6}\right][\mathrm{TFSI}]_{3}:$ To the suspension of $\mathrm{AlCl}_{3}(1.31 \mathrm{~g}, 9.84 \mathrm{mmol})$ in toluene $(20 \mathrm{~mL}), \mathrm{BIm}(7.33 \mathrm{~g}$, $59.0 \mathrm{mmol}$ ) was added dropwise and then the mixture was stirred for 24 hours at ambient temperature. The resulting crude compound and LiTFSI $(8.47 \mathrm{~g}, 29.5 \mathrm{mmol})$ was mixed together in acetonitrile $(30 \mathrm{~mL})$ for 2 days at room temperature. After removal of precipitated $\mathrm{LiCl}$ and solvent by filtration and evaporation, the remaining oil was diluted with $\mathrm{CH}_{2} \mathrm{Cl}_{2}(30 \mathrm{~mL})$, and then the precipitated impurities and the remaining solvent were removed to give $\left[\mathrm{Al}(\mathrm{BIm})_{6}\right][\mathrm{TFSI}]_{3}$ as a pale-yellow oil (12.1 g, $7.51 \mathrm{mmol}, 76.3 \%)$. Elemental analysis: calculated (\%) for $\mathrm{C}_{48} \mathrm{H}_{72} \mathrm{AlF}_{18} \mathrm{~N}_{15} \mathrm{O}_{12} \mathrm{~S}_{6}$ : C 35.75, Al 1.67; found: C 35.88, Al 1.82. 
Table S1. Crystallographic data for $\left[\mathrm{Al}(\mathrm{DMSO})_{6}\right][\mathrm{TFSI}]_{3},\left[\mathrm{Al}(\mathrm{DMSO})_{6}\right][\mathrm{TfO}]_{3}$ and $\left[\mathrm{Al}(\mathrm{MIm})_{6}\right][\mathrm{TFSI}]_{3}$.

\begin{tabular}{|c|c|c|c|}
\hline & {$\left[\mathrm{Al}(\mathrm{DMSO})_{6}\right][\mathrm{TFSI}]_{3}$} & {$\left[\mathrm{Al}(\mathrm{DMSO})_{6}\right][\mathrm{TfO}]_{3}$} & {$\left[\mathrm{Al}(\mathrm{MIm})_{6}\right][\mathrm{TFSI}]_{3}$} \\
\hline Chemical formula & $\mathrm{C}_{18} \mathrm{H}_{36} \mathrm{AlF}_{18} \mathrm{~N}_{3} \mathrm{O}_{18} \mathrm{~S}_{12}$ & $\mathrm{C}_{15} \mathrm{H}_{36} \mathrm{AlF}_{9} \mathrm{O}_{15} \mathrm{~S}_{9}$ & $\mathrm{C}_{30} \mathrm{H}_{36} \mathrm{AlF}_{18} \mathrm{~N}_{15} \mathrm{O}_{12} \mathrm{~S}_{6}$ \\
\hline Formula weight & 1336.20 & 942.99 & 1360.08 \\
\hline Crystal system & Trigonal & Monoclinic & Trigonal \\
\hline Space group & $R \overline{3}$ (no. 148$)$ & $P 2_{1} / c($ no. 14$)$ & $R \overline{3}$ (no. 148 ) \\
\hline$a / \AA$ & $16.0816(12)$ & $18.2012(11)$ & $23.329(2)$ \\
\hline$b / \AA$ & $16.0816(12)$ & $10.6387(7)$ & $23.329(2)$ \\
\hline$c / \AA$ & $17.4963(13)$ & $20.8590(13)$ & $8.6415(8)$ \\
\hline$\alpha /{ }^{\circ}$ & 90 & 90 & 90 \\
\hline$\beta /^{\circ}$ & 90 & $106.7404(9)$ & 90 \\
\hline$\gamma /{ }^{\circ}$ & 120 & 90 & 120 \\
\hline$V / \AA^{3}$ & $3918.6(7)$ & $3867.9(4)$ & $4073.0(8)$ \\
\hline$Z$ & 3 & 4 & 3 \\
\hline$D_{\text {calc }} / \mathrm{g} \mathrm{cm}^{-3}$ & 1.699 & 1.619 & 1.664 \\
\hline$\mu / \mathrm{mm}^{-1}$ & 0.644 & 0.637 & 0.398 \\
\hline Temp. $/{ }^{\circ} \mathrm{C}$ & -100 & -100 & -100 \\
\hline Reflections collected & 7583 & 21723 & 7731 \\
\hline Independent reflection, $R_{\text {int }}$ & $1992,0.0285$ & $8766,0.0456$ & $2068,0.0234$ \\
\hline$R_{1}[I>2 \sigma(I)]$ & 0.0554 & 0.0533 & 0.0996 \\
\hline$w R_{2}$ (all data) & 0.1541 & 0.1498 & 0.2984 \\
\hline GooF & 1.043 & 1.031 & 1.055 \\
\hline Largest residual density / e $\AA^{-3}$ & $-0.610 / 1.211$ & $-0.634 / 1.068$ & $-0.548 / 0.998$ \\
\hline
\end{tabular}




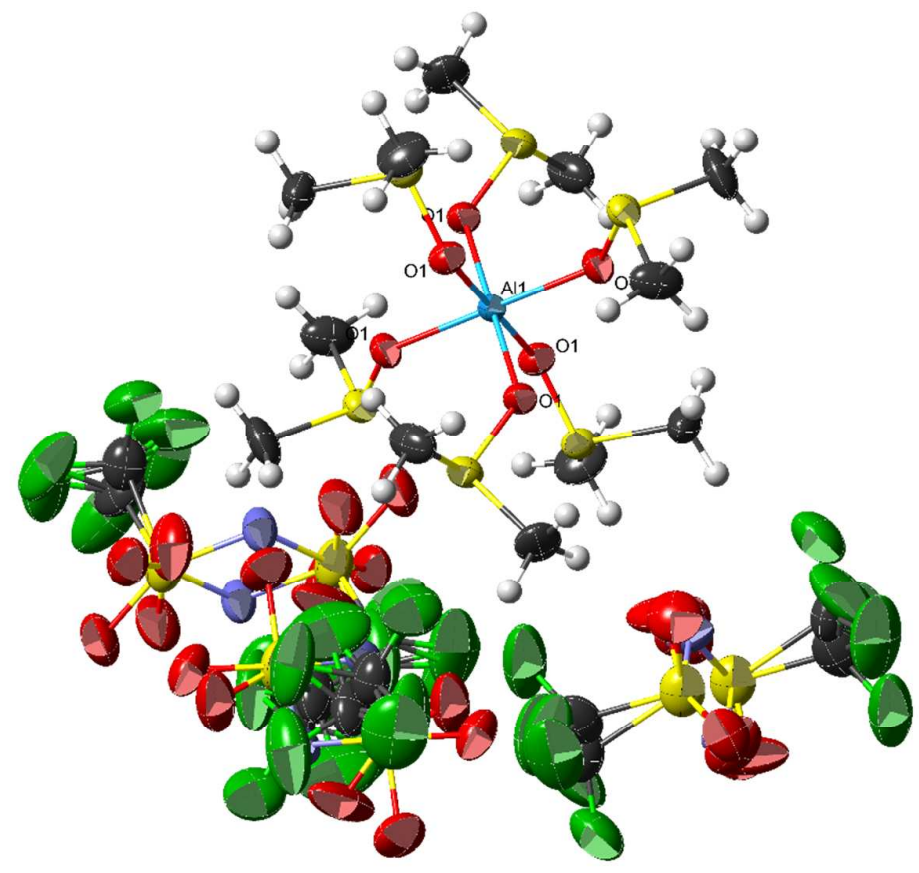

Figure S1. Thermal ellipsoid model of the crystal of $\left[\mathrm{Al}(\mathrm{DMSO})_{6}\right][\mathrm{TFSI}]_{3}$. Expanded structures with disordered atoms on TFSI anions are indicated. The ellipsoids of non-hydrogen atoms are drawn at the 50\% probability level, while isotropic hydrogen atoms are represented by spheres of arbitrary size. CCDC: 1440792. 


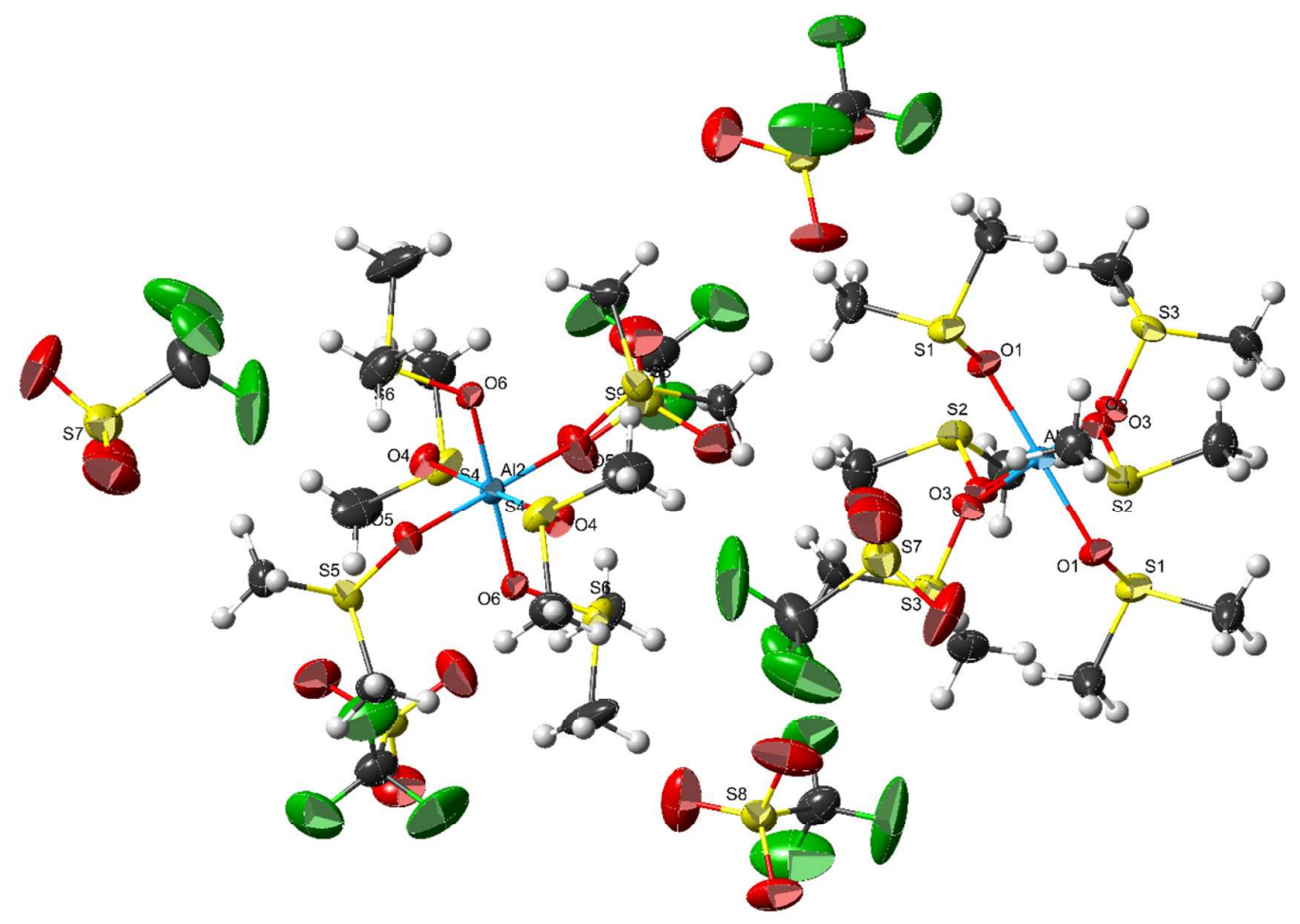

Figure S2. Thermal ellipsoid model of the crystal of $\left[\mathrm{Al}(\mathrm{DMSO})_{6}\right][\mathrm{TfO}]_{3}$. Expanded structures are indicated.

There are two independent $\left[\mathrm{Al}(\mathrm{DMSO})_{6}\right]^{3+}$ cations in the $\left[\mathrm{Al}(\mathrm{DMSO})_{6}\right][\mathrm{TfO}]_{3}$ crystal. The ellipsoids of non-hydrogen atoms are drawn at the $50 \%$ probability level, while isotropic hydrogen atoms are represented by spheres of arbitrary size. CCDC: 1440793 . 


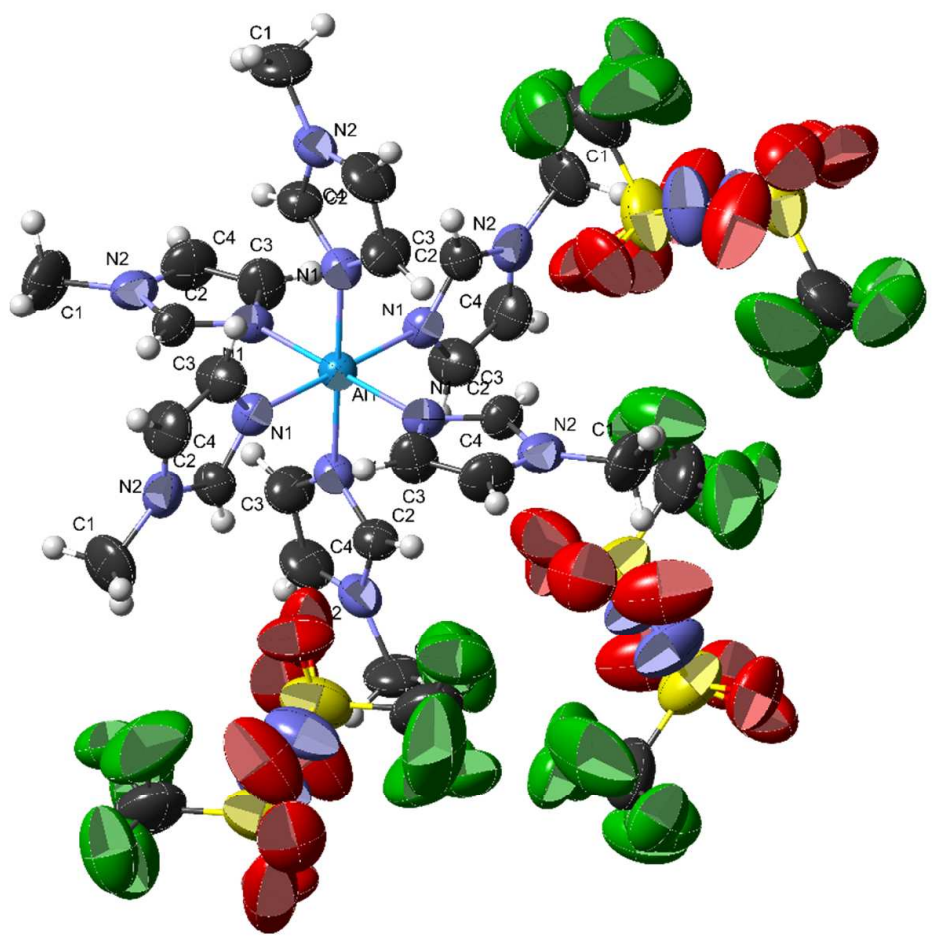

Figure S3. Thermal ellipsoid model of the crystal of $\left[\mathrm{Al}(\mathrm{MIm})_{6}\right][\mathrm{TFSI}]_{3}$. Expanded structures with disordered atoms on TFSI anions are indicated. The ellipsoids of non-hydrogen atoms are drawn at the $50 \%$ probability level, while isotropic hydrogen atoms are represented by spheres of arbitrary size. CCDC: 1454447. 

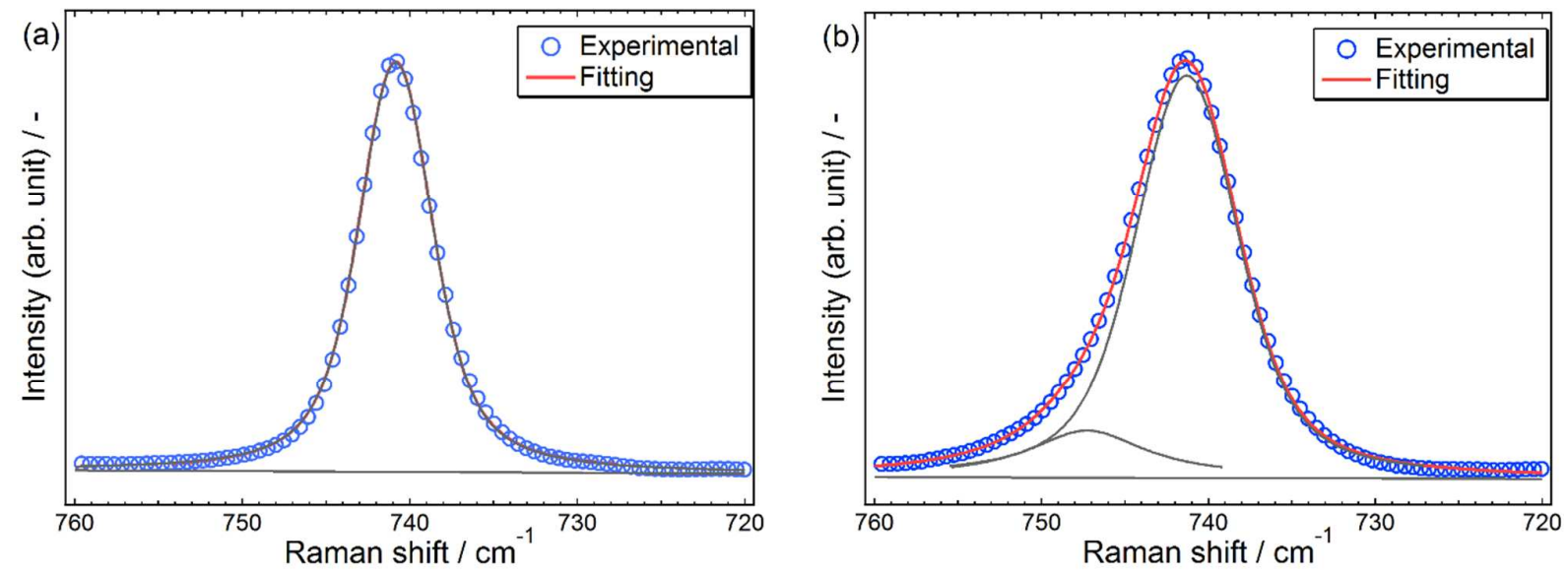

Figure S4. Deconvolution results of Raman spectra into two components at around 741 and $747 \mathrm{~cm}^{-1}$ by Voigt functions for (a) $\left[\mathrm{Al}(\mathrm{MIm})_{6}\right][\mathrm{TFSI}]_{3}$ in the crystalline state and (b) $\left[\mathrm{Al}(\mathrm{BIm})_{6}\right][\mathrm{TFSI}]_{3}$ in the liquid state.

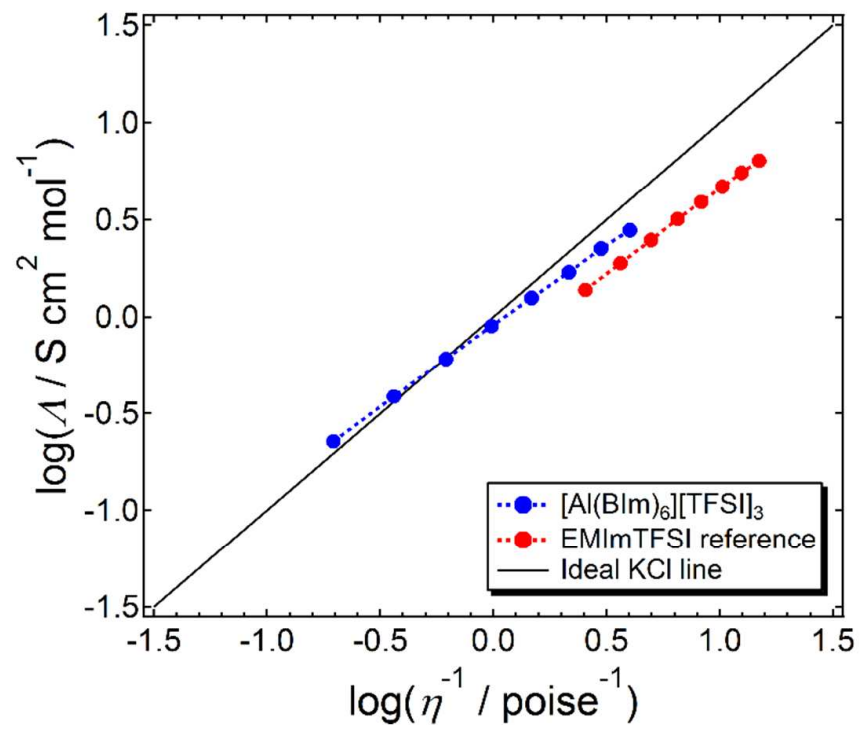

Figure S5. Temperature dependent Walden plot for $\left[\mathrm{Al}(\mathrm{BIm})_{6}\right][\mathrm{TFSI}]_{3}$, and EMImTFSI as reference, ${ }^{1}$ in the $20-90{ }^{\circ} \mathrm{C}$ range. The molar conductivities $(\Lambda)$ for $\left[\mathrm{Al}(\mathrm{BIm})_{6}\right][\mathrm{TFSI}]_{3}$ are provided as $1 / 3$ of the observed values to correct for the total charges (6) of the created dissociated species; $\left[\mathrm{Al}(\mathrm{BIm})_{6}\right]^{3+}$ and $3[\mathrm{TFSI}]$. 


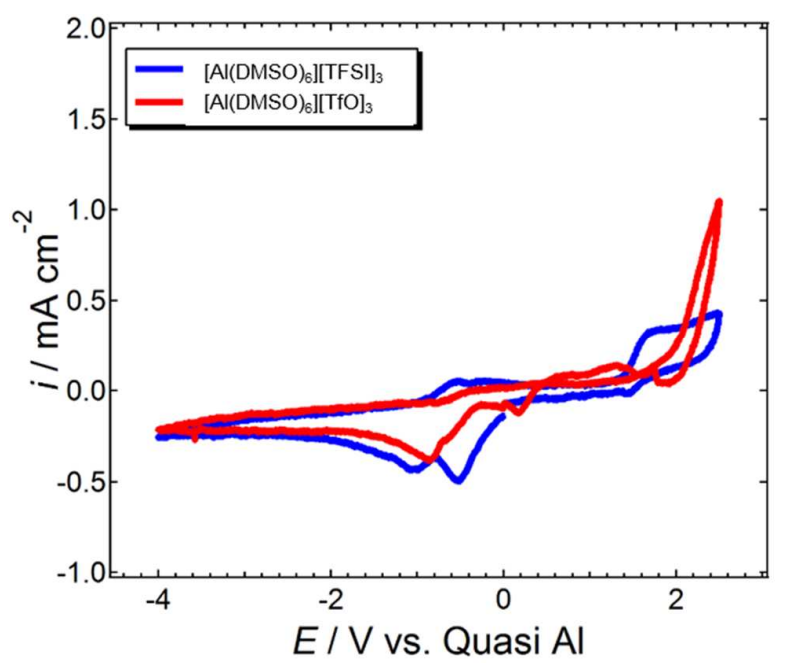

Figure S6. CVs recorded on a Pt electrode for $0.2 \mathrm{M}\left[\mathrm{Al}(\mathrm{DMSO})_{6}\right][\mathrm{TFSI}]_{3}$ and $\left[\mathrm{Al}(\mathrm{DMSO})_{6}\right][\mathrm{TfO}]_{3}$ in sulfolane, respectively.

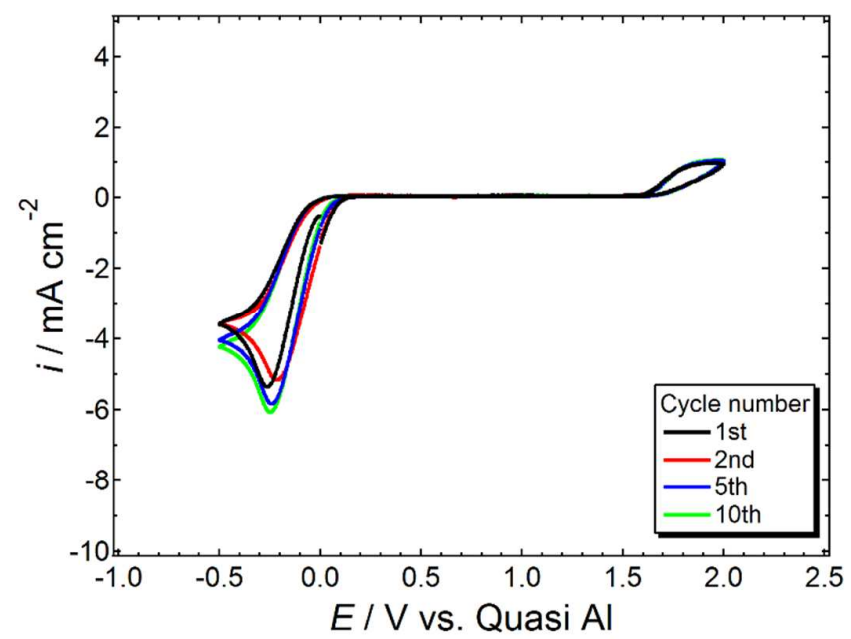

Figure S7. CV recorded on a Pt electrode for $0.2 \mathrm{M}\left[\mathrm{Al}(\mathrm{MIm})_{6}\right][\mathrm{TFSI}]_{3}$ in acetonitrile.

\section{Reference}

1. M. Kerner, N. Plylahan, J. Scheers, P. Johansson, Ionic liquid based lithium battery electrolytes: Fundamental benefits of utilizing both TFSI and FSI anions? Phys. Chem. Chem. Phys., 2015, 17, 19569 
19581. 